\title{
EXPERIMENTAL DETERMINATION OF CHANGING THE AXIAL FORCE IN THE BOLTS OF THE CLAMPING SLEEVE UNDER ITS AXIAL LOAD
}

\author{
HRUZÍK Lukášs*, STRUŽ Jiří1, KALÁB Květoslav ${ }^{1}$ \\ ${ }^{1} V S B$ - TU Ostrava, Faculty of Mechanical engineering, Department of machine parts and mechanisms, \\ 17. listopadu 2172/15, 70800 Ostrava,Czech Republic, e-mail: lukas.hruzik@vsb.cz.
}

\begin{abstract}
This paper deals about experimental determination of changing the axial load in the bolts of the clamping sleeve under its axial load. Inspiration for this experiment was FEM analysis clamping sleeve in Ansys workbench. Changing of the axial load in the bolts is very important for fatigue of bolt. Bolt force and pretension is necessary for transmit axial load and torque. the change occurs when the sleeve is loaded by the axial force.
\end{abstract}

KEYWORDS: Clamping sleeve, Bolt pretension, Experiment, Axial force, Strain gauge.

\section{Introduction}

This article deals about experimental determination of changing the axial load in the bolts. The change occurs when the sleeve is loaded by the axial force. Changing the axial bolt force has effect on a fatigue of bolts. May have effect on a contact pressure, where is necessary to transmit axial force and torque. About fatigue of a bolt pretension discusses for example [1]. According to [2] has load direction influence on the decrease or increase bolt axis force and bolt pretension. There was always a decrease in the FEM analysis [6]. Direction of a Load did not had effects on the decrease or increase.

The experiment was performed on a burst machine. The load on a clamping sleeve during the experiment was only a tensile force without transmitted torque. There was used TLK $40050 \times 80$. Dimension and type clamping sleeve had selected with respect to practicability of experiment. A detailed theoretical analysis of the experiment and calibration of the screws is given in [3] and had published on ICMD 2020.

\section{Measuring principle}

Measuring were realizing with strain gauges. Each bolt was including two strain gauges. Strain gauges was connecting separately and independently. Thanks to this connection, we were able to get to know bending on the bolts. Two strain gauge connection separately are complicated for the calibration, example of these connection is in [4], [5].
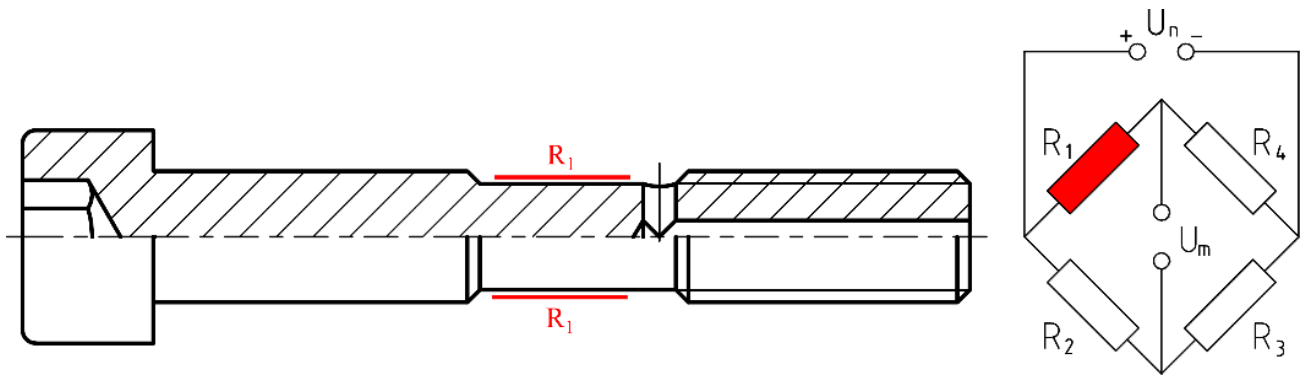

Fig. 1 Strain gauges on bolt 


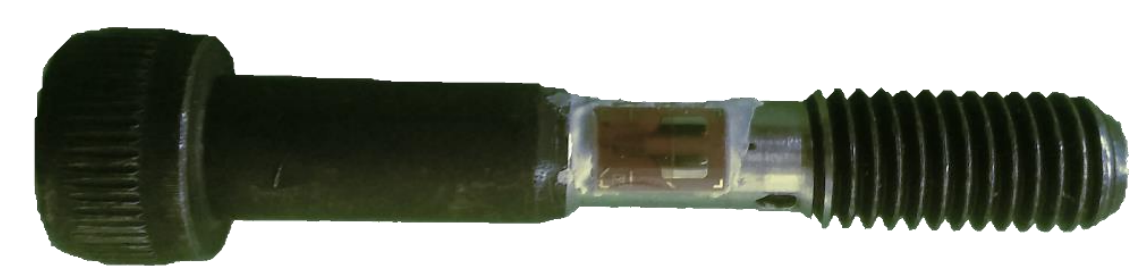

Fig. 2 Strain gauge bonded on the bolt

Due to axial drilling of screws, had to be reducing pretension axial force in bolts and tightening moment of the bolts. For calculation tightening moment must be applicated numerical method on Mathcad software. the reason is the ignorance of the friction conditions on the screw. Calculation principle is in [3].

Axial force in original bolts:

$$
\begin{gathered}
F_{o p}=\frac{\sigma_{d}}{\sqrt{\left(\frac{\operatorname{tg}\left(\psi+\varphi^{\prime}\right) \cdot \frac{d_{2}}{2}}{\frac{\pi}{16} \cdot\left(\frac{d_{3}^{4}-d_{p}^{4}}{d_{3}}\right)}\right)^{2}+3 \cdot\left(\frac{1}{\pi \cdot\left(d_{3}^{2}-d_{p}^{2}\right) \cdot \frac{1}{4}}\right)^{2}}}=\frac{1080}{\sqrt{\left(\frac{\operatorname{tg}(3,168+6,587) \cdot \frac{7,188}{2}}{\frac{\pi}{16}\left(\frac{6,466-2}{6,466}\right)}\right)^{2}+3 \cdot\left(\frac{1}{\pi \cdot(6,466-2) \cdot \frac{1}{4}}\right)^{2}}}= \\
27448,9 \mathrm{~N}
\end{gathered}
$$

Reduced axial force:

$$
F_{o p}=15000 \mathrm{~N}
$$

For measuring had producing some parts for connection pretension clamping sleeve on the burst machine. Clamping sleeve was loaded push or pull axial force.
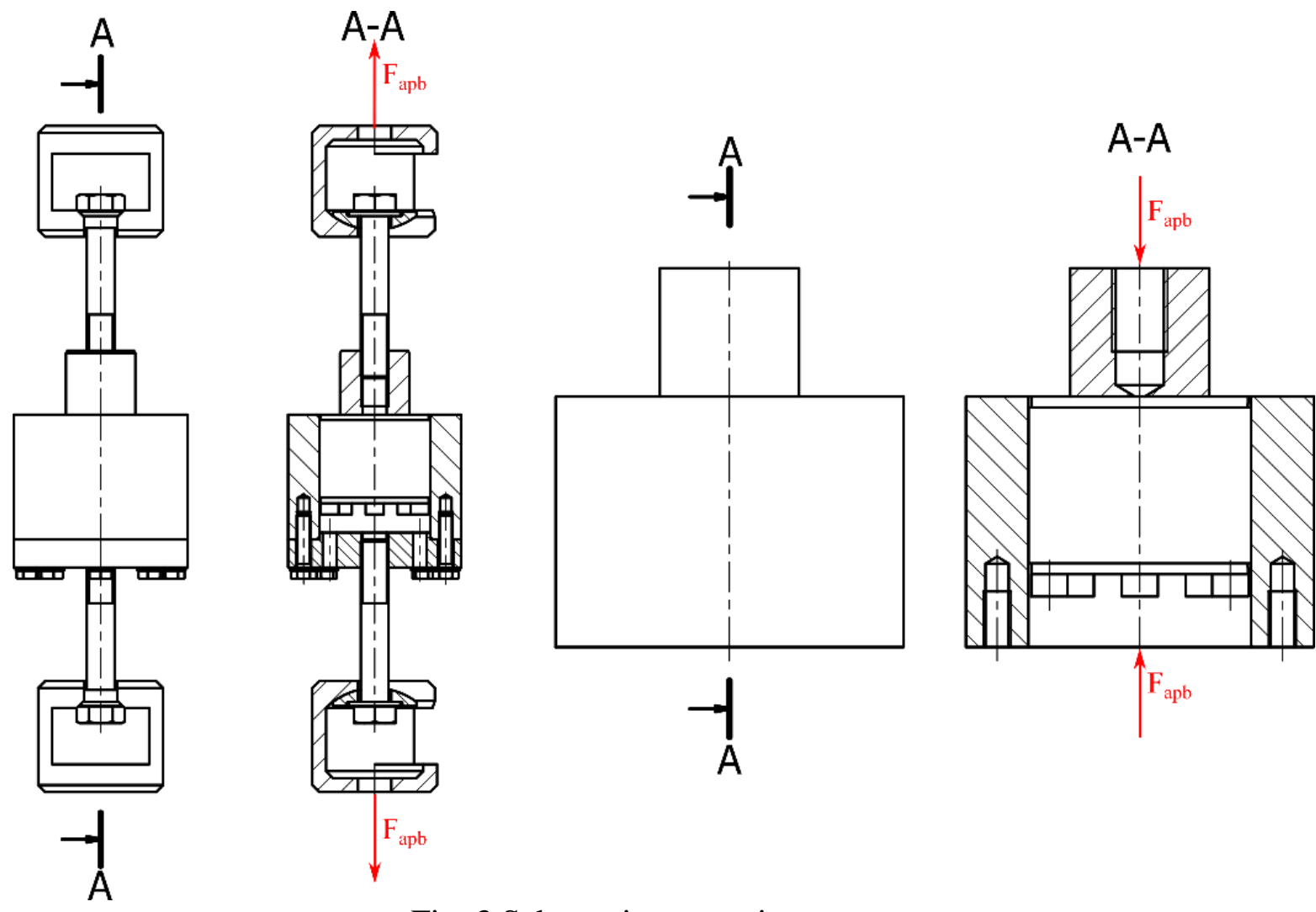

Fig. 3 Schematic measuring process

Due to reduced bolt pretension had to reducing force for measuring:

$$
F_{a p b}=\frac{\pi \cdot p_{w p} \cdot d_{w} \cdot L_{w} \cdot f}{k_{p}}=\frac{\pi \cdot 81,5 \cdot 50 \cdot 56 \cdot 0,1344}{1,122}=85940 \mathrm{~N}
$$


For tightening were applicating procedure giving from producer. For this procedure is necessary tightening moment. Tightening moment was determining on $20 \mathrm{Nm}$, this is a safe moment for drilled bolts. Tightening procedure is writing in [7]. The minimum torque according to the manufacturer is $40 \%$ of the maximum, which is met.

\section{$3 \quad$ Measuring process}

Measure were realizing on burst machine with axial push-pull load. For measuring axial force in bolts have used strain gauges. These gauges were connecting to virtual instrument measuring card from National instruments producer. Concretely NI 9237. For measuring have used four measuring cards, each with four canals. Clamping sleeve has eight bolts, each with two strain gauges. Measuring have doing for Static Case with very slowly raising axial force.

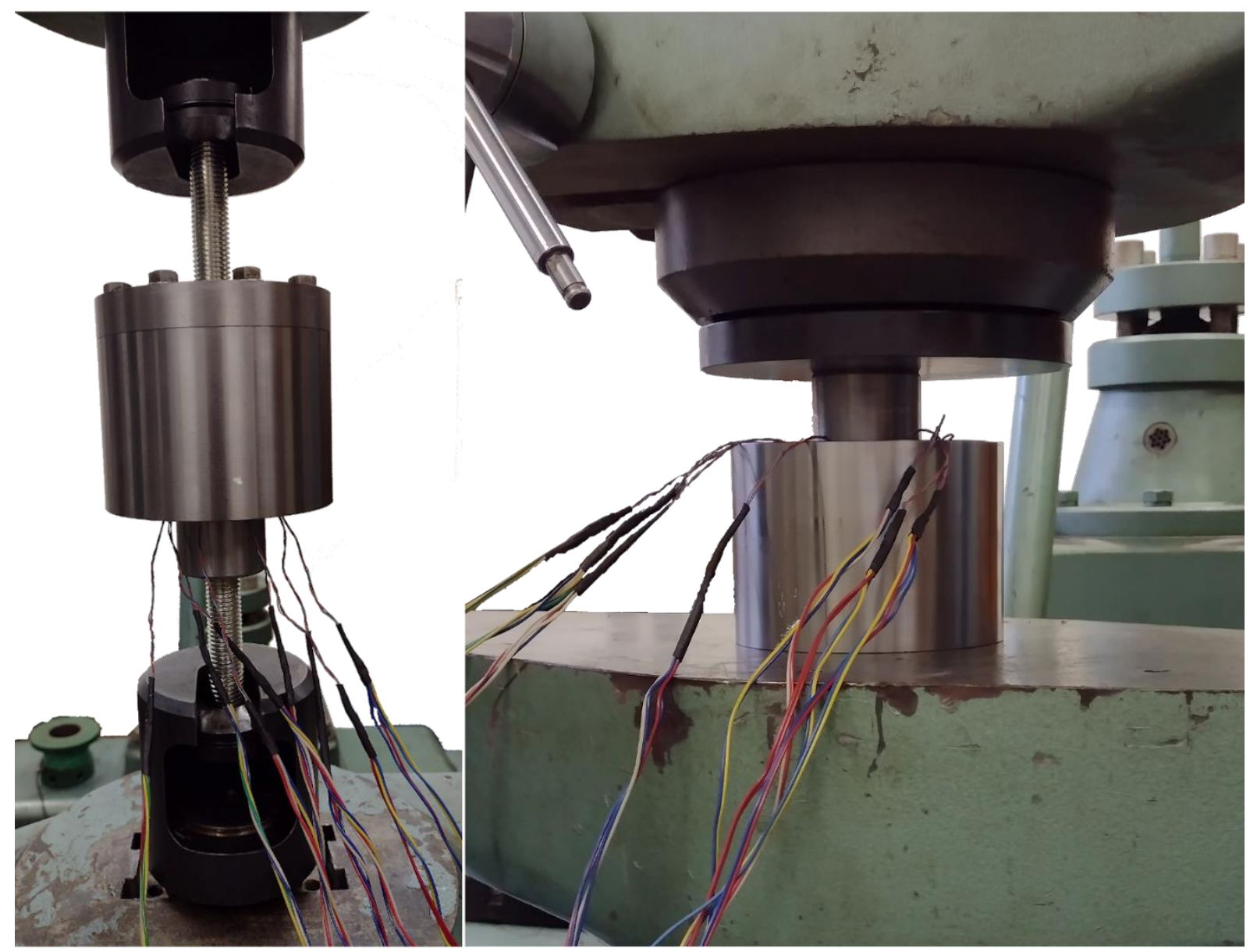

Fig. 4 Photos during measuring

Push load case show decrease axis force in bolt. Just like in push case, pull case show decrease axis force in bolts.

During the measuring was processing than bolt pretension no return on original pretension after unloading clamping sleeve. Pretension decrease occur will only at the first load after installation. The bolts are not loaded on fatigue.

In plots is for each bolt value calculated as average from both strain gauges. The variance of the values is given by the tightening procedure from manufacturer of clamping sleeve. The producer prescribes tightening on tightening moment. In first step on half tightening moment crossed bolts, after on a full tightening moment crossed bolts finally twice clockwise on a full 
tightening moment. After this procedure is pretension different between each bolt, this different pretension is show in a plot Fig. 5 .

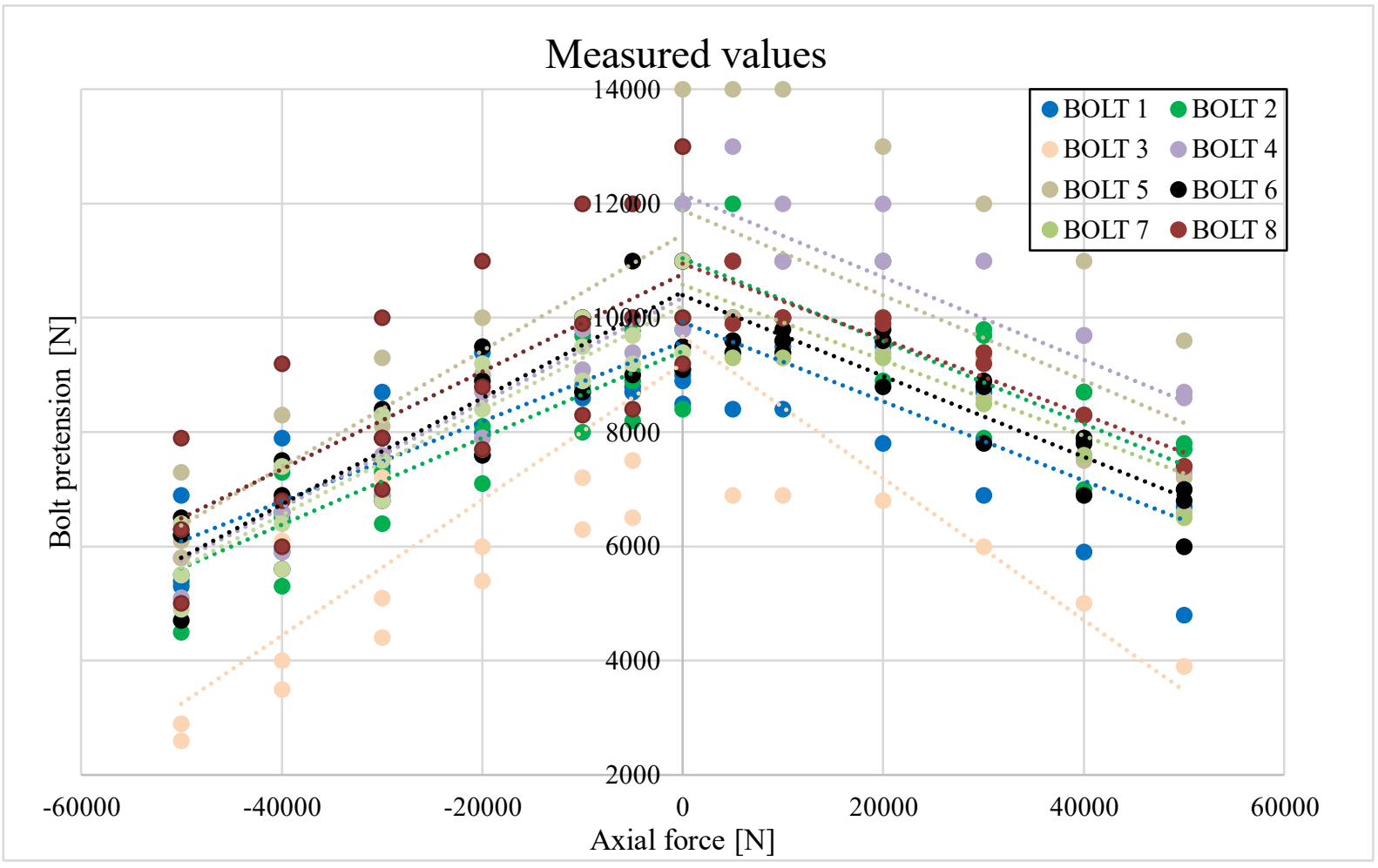

Fig. 5 Measured values for each bolt

For authorization of this hypothesis have doing FEM analysis of experiment.

\section{$4 \quad$ FEM Analysis of experiment}

Experiment were analysing in Ansys Workbench. Where were using a static case for push and pull case. In both cases were using contact analysis with contact on conical surface and nonlinear solution these analyses. Frictional coefficient on the conical surface and shaft or hub have used 0,1344 . This number were calculated with numerical method, description on [3]

Frictional - Solid To Solid
01.10.2020 12:39

$\square$ Frictional - Solid To Solid
Frictional - Solid To Solid $01.10 .202012: 38$
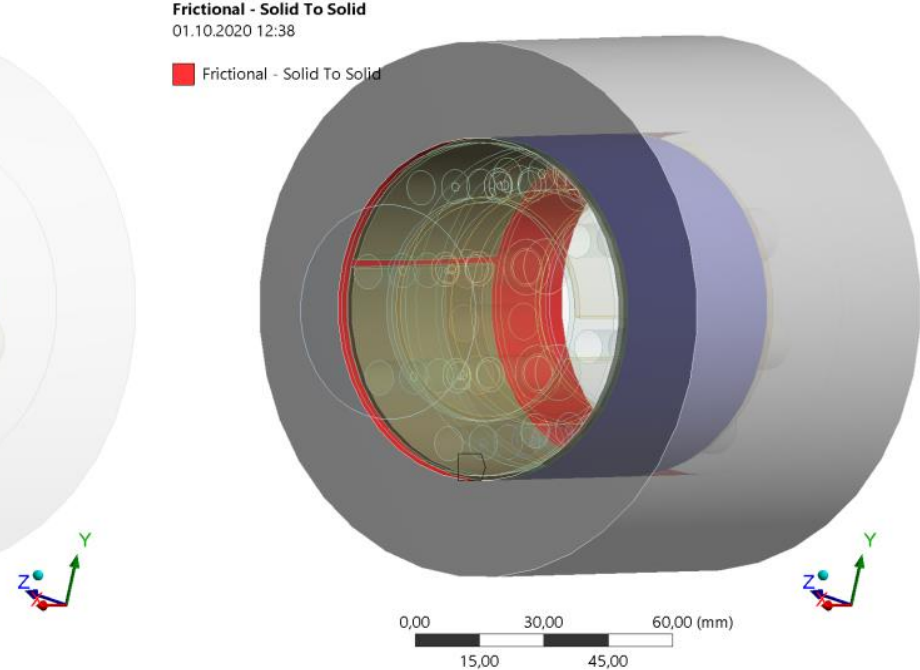

$0,00 \quad 30,00 \quad 35,00(\mathrm{~mm})$

Fig. 6 Shaft - inner ring and outer ring - hub contact 
Other contacts are on the conical surfaces, again with frictional coefficient 0,1344 from numerical method.
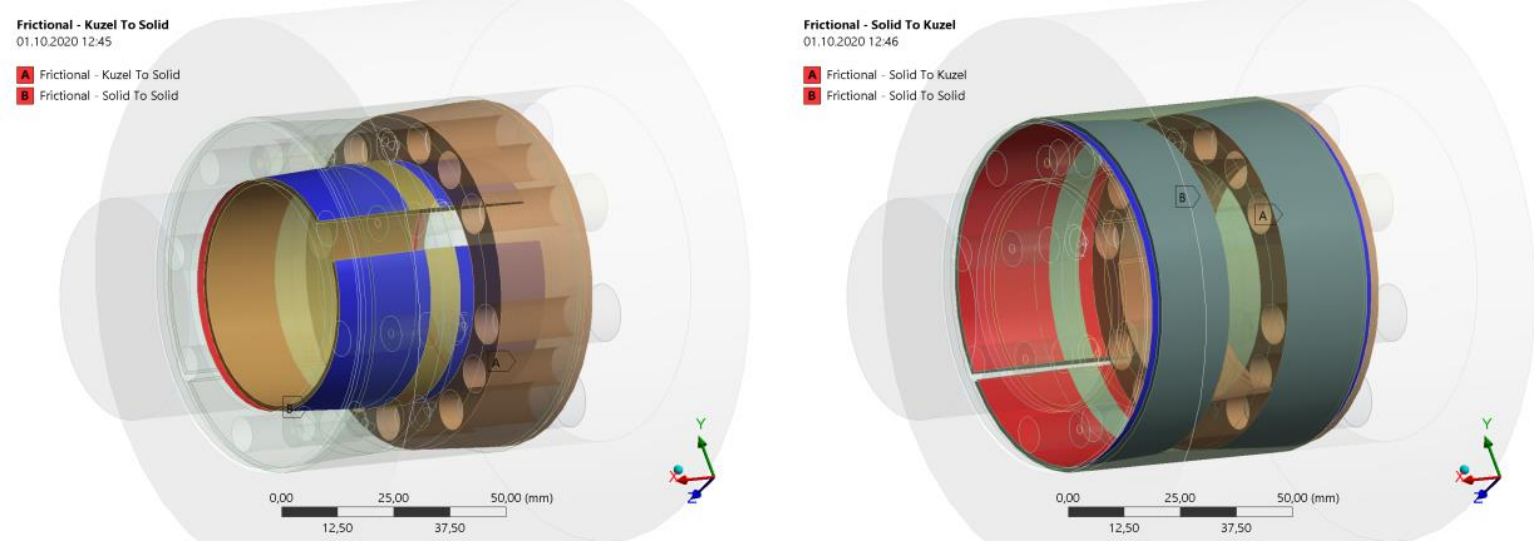

Fig. 7 Conical surface contact

I used frictionless contact under bolt head for easier convergency, in thread was bolt connection with bonded contact.
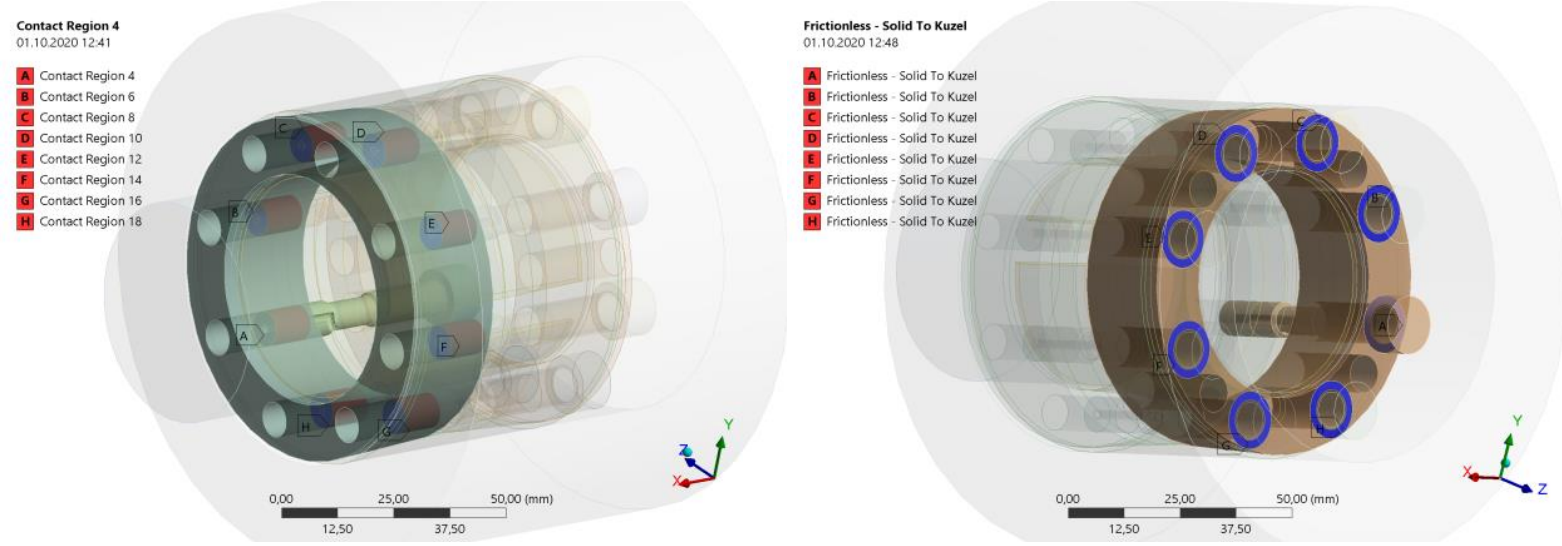

Fig. 8 Bolt contact

There has been used analysis with two steps. In first step have applicated preload on the bolts. Preload have defined in pretension force. Force were determining from experiment, where was bolt tightening on $20 \mathrm{Nm}$. In second step were applicating measuring axial force.
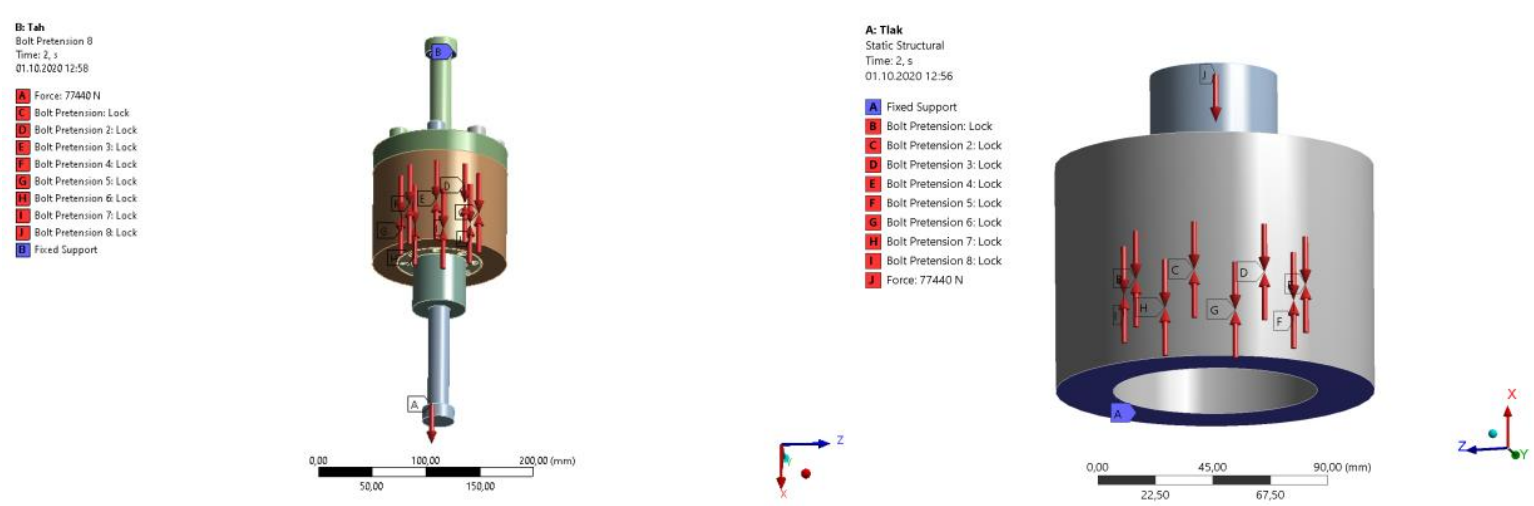

Fig. 9 Push and pull analysis

The output of this analysis was mainly a plot of the dependence of the loading force on the axial force in the bolts. Decrease in pretension obtained by FEM is very linear. Tangent of the curve is very similar for each bolt. The differences between them are probably due to the inaccuracy of the FEM method. The decrease is the same for push and pull case. Fig. 10. 


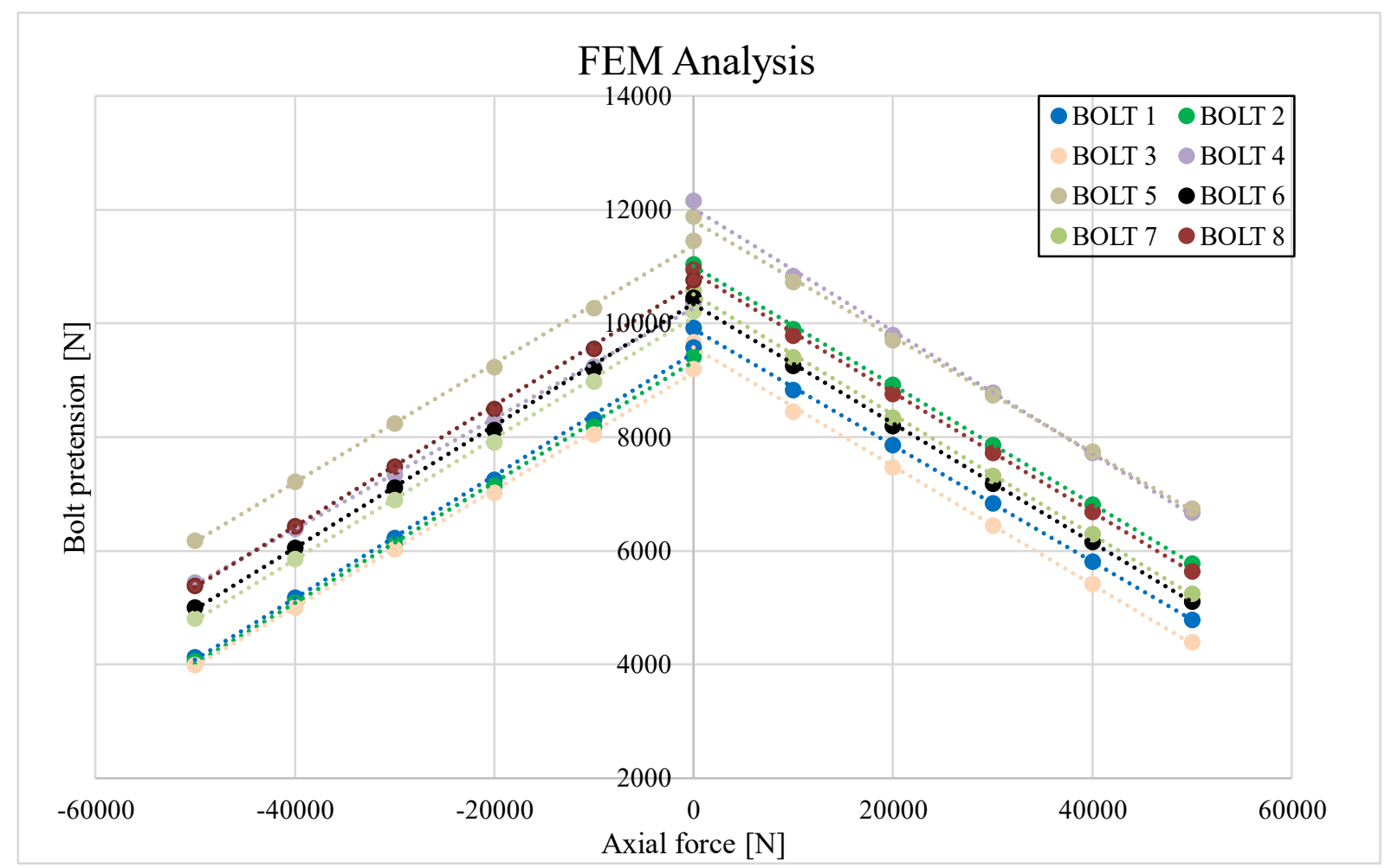

Fig. 10 FEM Analysis result

\section{Comparison measurement and FEM analysis result}

Difference between measurement and FEM analysis is best seen on the plot. In plot Fig. 11 is values for all bolts on case and method approximated with only one linear curve. For this reason, is more scatter of values around linear curve. Advantage of this layout is clarity of the plot. We compare only four curves.

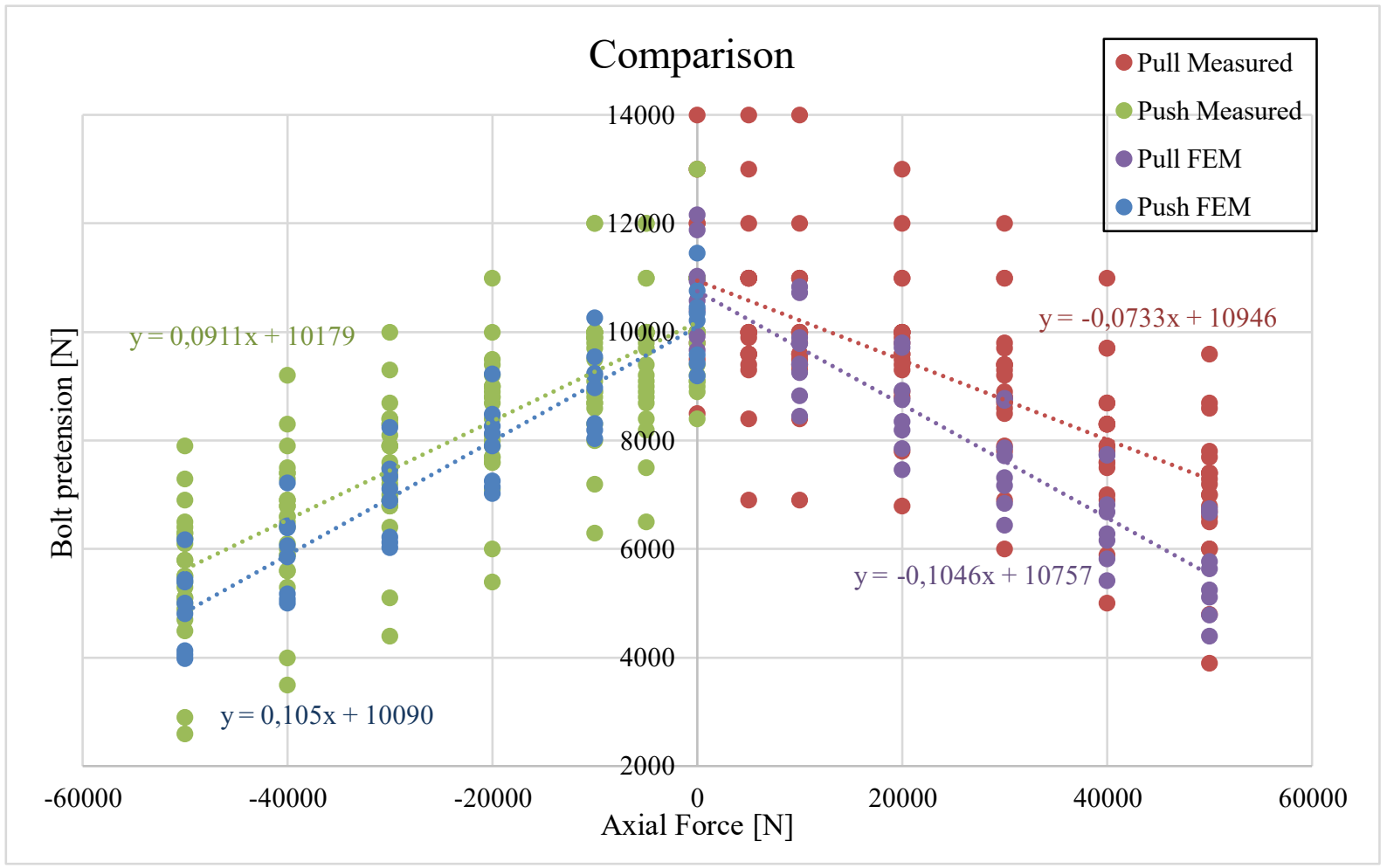

Fig. 11 Results comparison 
I attribute, the difference in the decrease of the FEM curves and measured curves inaccurately designated of frictional coefficient. Theoretical frictional coefficient determined from numerical method will not same frictional coefficient on physical clamping sleeve. The difference is small enough in my opinion, I consider the FEM analysis to be well setup.

\section{CONCLUSION}

Measurements were making with respect to the detection of the decrease pretension in the bolts of the clamping sleeve during its loading by the axial force. The preload was measure using strain gauges located on the modified clamping sleeve bolts. The load was created using a bursting machine and was realized both for the case of push and pull. A plot was plott for both cases. The hypothesis of bolt loading on fatigue was not confirmed. The preload only drops when the housing is first loaded and remains at a reduced level. This brings another problem.

Due to very low preload remaining on the bolts and with combination for example vibration, the bolts may come loose. This is very dangerous for safety working of the machine and for transmit torque or axial force.

The reason for the loss of preload could be landing conical surface, which take over the load from the bolt. Self-locking prevents the cones from releasing back. In my opinion, several factors affect the magnitude of the preload drop for example surface roughness, lubrication, bending of the bolts etc. The bending can be solved, for example, according to [8] There is the possibility of further research in this area.

\section{ACKNOWLEDGEMENT}

This article was developed within the project SP2021/31 - „Experimentální a výpočtové metody dimenzování strojních součástí 2021 “

\section{REFERENCES}

[1] Pospíšil, F. “Závitová a šroubová spojení”, Vyd. 1. Praha: SNTL - Nakladatelství technické literatury, 1968.

[2] Kaláb, K. “Části a mechanismy strojů pro bakaláře: části spojovací [záznam a]”, 1. vyd. Ostrava: VŠB - Technická univerzita Ostrava, 2007. ISBN 9788024812908.

[3] Hruzík, L., Struž, J., Kaláb, K. “Theoretical analysis of the experiment: Changing the axial force in the bolts of the clamping sleeve under its axial load", In: ICMD 2020 - 61st International Conference of Machine Design Departments. Košice, 2020.

[4] Začal, J., Folta, Z., Jančar, L. "Design of a sensor for measurement of bolt pretension", In: 58th International Conference of Machine Design Departments (ICMD), Kamycka 129, Prague 6165 21, Czech republic, Czech University Life Sciences Prague, Dept Systems Eng, pp. 426 - 429, 2017.

[5] Folta, Z. “Odporová tenzometrie”, Pracovní verze C. 2009.

[6] Onduška, J., Šooš, L., Onderová, I., Čacko, V. "Feedback FEM analysis to the material properties in the simulation of radial pressure in the cylindrical chamber", In Applied Mechanics and Materials 832: selected, peer reviewed papers from the 21st International Conference "Engineering for Environment Protection - TOP", Senec, SR, 23. - 25. 6. 2015, pp. 213 - 217, 2016. ISSN 1660-9336

[7] "Rexnord Tollok Locking Assemblies Catalog Metric", [online] Available at: https://www.rexnord.com/contentitems/techlibrary/documents/pt2-001m_a4_catalog, [Accessed: 26 January 2021]. 
[8] Welch, M. "Analysis of Bolt Bending in Preloaded Bolted Joints", Strojnícky časopis Journal of Mechanical Engineering 68 (3), pp. 183 - 194, 2018. DOI: 10.2478/scjme2018-0034 